UNITED STATES DEPARTMENT OF THE INTERIOR

GEOLOGICAL SURVEY

\title{
HIGH-PRECISION GRAVITY NETWORK TO MONITOR TEMPORAL VARIATIONS IN GRAVITY ACROSS YUCCA MOUNTAIN, NEVADA
}

By

R. N. Harris and D. A. Ponce

1988

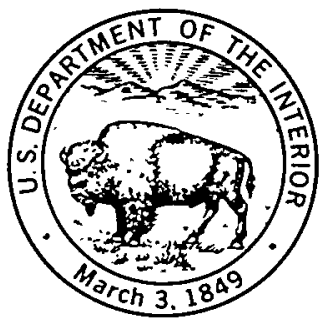

\section{REPRODUCED FSOM BEST AVAILABLE COPY}

Open-File Report 88-243

Prepared in cooperation with the

Nevada Operations Office

U.S. Department of Energy

(Interagency Agreement DE-AI08-78ET44802)

This report is preliminary and has not been reviewed for conformity with U.S. Geological Survey editorial standards and stratigraphic nomenclature. Any use of trade names is for descriptive purposes only and does not imply endorsement by the U.S. Geological Survey.

Menlo Park, California 1988 
Copies of this Open-File Report

may be purchased from

Books and Open-File Reports Section

Branch of Distribution

U.S. Geological Survey

Box 25425, Federal Center

Denver, CO 80225

PREPAYMENT IS REQUIRED

Price information will be published in the monthly listing

New Publications of the Geological Survey

FOR ADDITIONAL ORDERING INFORMATION

CALL: (303) 236-7476

REPRODUCED FROM BEST AVALABLE COPY 
UNITED STATES

DEPARTMENT OF THE INTERIOR

GEOLOGICAL SURVEY

HIGH-PRECISION GRAVITY NETWORK TO MONITOR TEMPORAC VARIATIONS IN GRAVITY ACROSS YUCCA MOUNTAIN, NEVADA

$$
\text { By }
$$

R. N. Harris and D. A. Ponce ${ }^{1}$

GEOLOGICAL SURVEY OPEN-FILE REPORT 88-243

1 U.S. Geological Survey, Menlo Park, CA

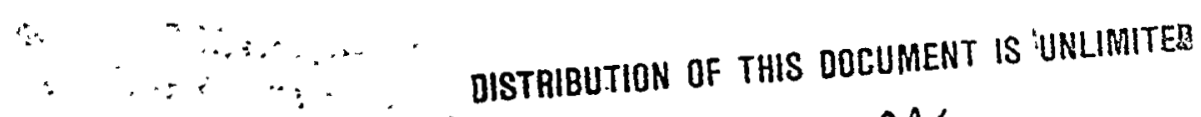




\section{DISCLAIMER}

This report was prepared as an account of work sponsored by an agency of the United States Government. Neither the United States Government nor any agency thereof, nor any of their employees, make any warranty, express or implied, or assumes any legal liability or responsibility for the accuracy, completeness, or usefulness of any information, apparatus, product, or process disclosed, or represents that its use would not infringe privately owned rights. Reference herein to any specific commercial product, process, or service by trade name, trademark, manufacturer, or otherwise does not necessarily constitute or imply its endorsement, recommendation, or favoring by the United States Government or any agency thereof. The views and opinions of authors expressed herein do not necessarily state or reflect those of the United States Government or any agency thereof. 


\section{DISCLAIMER}

Portions of this document may be illegible in electronic image products. Images are produced from the best available original document. 


\section{CONTENTS}

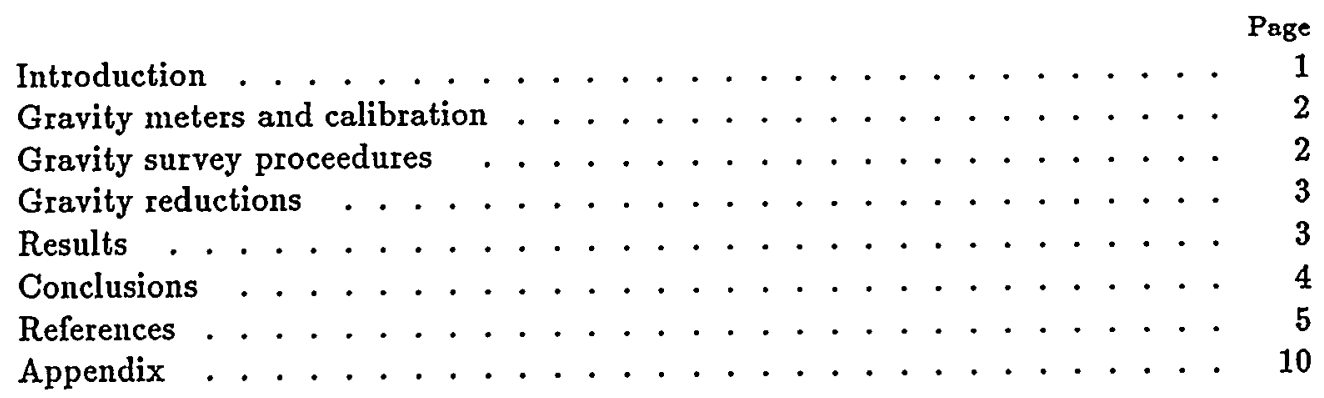

\section{ILLUSTRATIONS}

Page

FIGURE 1. Digital terrain model with station locations . . . . . . . . 6 2. Plot of average changes in gravity of station pairs . . . . . 7

\section{TABLES}

TABLE 1. Meters used and their correction factors . . . . . . . 8

2. Gravity differences of stations . . . . . . . . . . 8

3. Average gravity differences of station pairs . . . . . . 9 


\section{INTRODUCTION}

Repeatable high-precision gravity surveys provide a method of monitoring temporal variations in the gravity field. Fluctuations in the gravity field may indicate water table changes, crustal deformation, or precursors to volcanism and earthquakes. This report describes a high-precision gravity loop which has been established across Yucca Mountain, Nevada in support of the Nevada Nuclear Waste Storage Investigations (NNWSI) program. The purpose of this gravity loop is to monitor temporal variations in gravity across Yucca Mountain in an effort to interpret and predict the stability of the tectonic framework and changes in the subsurface density field. Studies of the tectonic framework which include volcanic hazard, seismicity, and faulting studies are in progress (USGS, 1984; Department of Energy, 1988, v. 5).

Repeat high-precision gravity surveys are less expensive and can be made more rapilly than a corresponding leveling survey. High-precision gravity surveys are capable of detecting elevation changes of 3 to $5 \mathrm{~cm}$, and thus, can be employed as an efficient tool for monitoring vertical crustal movements while supplementing or partially replacing leveling data.

The Yucca Mountain gravity network has been tied to absolute gravity measurements established in southern Nevada (Zumberge and others, 1988). These ties provide an absolute datum for comparing repeat occupations of the gravity network, and provide a method of monitoring broad-scale changes in gravity. Absolute gravity measurements were also made at the bottom and top of the Charleston Peak calibration loop in southern Nevacla (Ponce and Oliver, 1981). These absolute gravity measurements provide local control for calibrating gravity meters over the gravity ranges observed at Yucca Mountain.

Temporal variations in gravity may result from vertical movements along the free-air gradient (i.e., changes in elevation) or a variation in the subsurface density field. To discriminate between these two phenomena the gravity loop has been established along a first-order geodetic level-line that may be periodically resurveyed to monitor changes in elevation. Elevation changes over the level-line between 1983 and 1986 are less than $0.5 \mathrm{~cm}$ (T.D. Gilmore, written commun., 1987). If significant changes in gravity and elevation occur, these changes can be correlated to model the deformation. Additionally, other geophysical methods could be utilized to help delineate the deformation such as seismicity, drill holes, or hole-to-hole refraction.

Jachens (1978) summarized the relationship between gravity and elevation changes for a variety of geologic environments, and concluded that the general relation between gravity and elevation change is -2 to $-4 \mu \mathrm{Gal} / \mathrm{cm}$ which is on the order of the free-air gradient $(-3.09$ $\mu \mathrm{Gal} / \mathrm{cm})$. However, he cautions that the relation between gravity change and elevation change may assume a wide range of values, and variations in the subsurface density field may enhance, subdue, or dominate gravity changes resulting from vertical displacements.

Repeat high-precision gravity surveys have been successfully employed to study ground water systems and document tectonic and volcanic activity. Oliver and others (1975) reported gravity changes up to $0.45 \mathrm{mGal}$ following the San Fernando, California earthquake of 1971 . Based on their studies of the relation between the change in gravity and elevation they were able to model changes in Bouguer gravity anomalies caused by deformation associated with slip on subsurface faults. Jachens and others (1976) studied the relation between the change in gravity and elevation during the deflation of the Kilauea Volcano, Hawaii after the November 29, 1975 earthquake and eruption. Their data indicate a good correlation between gravity changes and elevation changes and document mass movement beneath the summit of Kilauea. Isherwood (1977) used high-precision gravity surveys and leveling data to monitor the water table at The Geysers, California geothermal area. He reported a net mass loss in the resevoir region which coincided with the production area and concluded that the fluid being removed was not being recharged. 


\section{GRAVITY METERS AND CALIBRATION}

The high-precision gravity loop over Yucca Mountain, Nevada was established and reoccupied with LaCoste and Romberg model D and G gravity meters with electronic galvanometers. The meters used in this report are listed in table 1 . The reading accuracy of the two gravity meter models is considered to be about 1 and $2 \mu \mathrm{Gal}$, respectively. With multiple readings over closed loops these meters are capable of yielding gravity differences with uncertainties of 4 to $6 \mu \mathrm{Gal}$ (H. W. Oliver and S. L. Robbins, written commun., 1975; Jachens and others, 1983). However, with larger observed gravity differences between stations, the calibration of the gravity meters becomes increasingly important.

Factory calibration tables were supplemented with correction factors based on repeated measurements made over the Charleston Peak (Ponce and Oliver, 1981) and the Mt. Hamilton (Barnes and others, 1969) calibration loops. The correction factors applied to the factory calibration tables are listed in table 1. Measurements made on these loops confirm that there was no significant change in the calibration of the meters between the surveys. Comparisons of differences between absolute and relative gravity measurements made on the top and bottom of the Mt. Hamilton calibration loop indicate that the improved calibration factors are accurate to 1 part in 10,000 (Harris and Roberts, written commun., 1987).

\section{GRAVITY SURVEY PROCEEDURES}

The Yucca Mountain high-precision gravity loop consists of eight station pairs, three across Crater Flat, two on the ridge of Yucca Montain, and three on the east side of Yucca Mountain (fig. 1). At the present time the only access to the stations in Crater Flat is through Steves Pass at station 3TJS, effectively dividing the loop into two parts. Originally, stations 59TJS through 39TJS were occupied on one day (6 to 7 hours) and stations 3TJS through 39TJS were occupied the next day ( 6 to 7 hours), including a hike up the west side of Yucca Mountain to reach station 39TJS. However, by obtaining access through the Lathrop Wells security gate, all of the stations can be occupied in one day (10 to 11 hours). Stations 39TJS through 59TJS are occupied as a set, and then stations 3TJS through 31TJS are occupied. This configuration is more efficient and eliminates the need to hike up the west side of Yucca Mountain. Arrangements to access the Lathrop Wells security gate must be obtained beforehand and are arranged by contacting NTS security. The loop can be occupied all year, but summer heat beginning in mid-June and lasting through August may adversely affect meter performance, and winter snow may make the stations difficult to locate.

Stations used in repeat high-precision gravity surveys must be accurately relocatable. Detailed descriptions of the stations comprising the Yucca Mountain high-precision gravity loop are presented in the appendix. Stations were established in pairs (designated as primes and alternates) so that differences in meter readings between each member of the pair could be compared to a known difference at the time of measurement. This ensures that the meters are performing properly and reduces operator error. The prime member of each pair was established on top of the first order level-line bench mark and the alternate member is marked with a $3.5 \mathrm{~cm}$ diameter brass disc stamped with the appropriate station name. To reduce possible sources of error due to site relocation problems which might introduce errors due to local terrain or magnetic influences, holes for the legs of the base plates were star-drilled into the bedrock, and gravity meters were read facing north. Thus, the reading position of the gravity meters can be recovered to better than about $1 \mathrm{~cm}$ vertically and $3 \mathrm{~cm}$ horizontally. Assuming a free-air gradient of $3 \mu \mathrm{gal} / \mathrm{cm}$, a $1 \mathrm{~cm}$ vertical uncertainty contributes an uncertainty of $3 \mu \mathrm{gal}$ to the standard error. 
All gravity measurements were made along closed loops originating from the absolute station at Mercury (MERCA). Generally each station was occupied twice during a day, with three gravity meters. Additionally the absolute gravity station at Test Cell C (TCCA) was occupied before and after reading stations on the east side and on top of Yucca Mountain. In order to minimize clamp hysteresis effects a fixed time of about 5 minutes between unclamping and reading the gravity meters was maintained.

\section{GRAVITY REDUCTIONS}

Gravity meter readings were converted to $\mathrm{mGal}$-equivalents using the factory calibration tables and the correction factors listed in table 1. Earth-tide corrections were applied to the measurements, calculated from the formulation of Longman (1959). The data were then examined for evidence of sudden changes in the readings or 'tares' and corrections were applied where necessary. Finally, the data from each day were analyzed by means of a leastsquares procedure. The system unknowns include the relative gravity between the base and the field stations, and the coefficients of time dependent drift polynomials.

\section{RESULTS}

The Yucca Mountain high-precision gravity loop was first occupied in June 1985 and reoccupied in November 1985 and June 1986. The stations were measured relative to the absolute gravity station at Mercury, Nevada (MERCA), using an observed gravity value of $979,518.974 \mathrm{mGal}$ at the floor based on absolute gravity measurements (Zumberge and others, 1988). Observed gravity values based on the June, 1985 occupation are reported in the station descriptions (see appendix). Gravity differences at all stations, relative to the absolute gravity station at Mercury, Nevada (MERCA) are given in table 2. The average uncertainty at each station of the relative gravity values are 4 to $6 \mu \mathrm{Gal}$ (one computed standard error). Gravity differences of the November 1985 and June 1986 occupations relative to the original June 1985 occupation are listed in table 3 . The uncertainties of this comparison range from about 7 to $10 \mu \mathrm{Gal}$. Figure 2 is a plot of the average change in gravity at each station pair showing their standard error (68\% confidence interval) and the $95 \%$ confidence interval. In general, the average changes at each station pair are within their standard error indicating that there has been no measurable change in gravity.

Data with uncertainties of 7 to $10 \mu \mathrm{Gal}$ are capable of detecting elevation changes of about 3 to $5 \mathrm{~cm}$. The present data are also precise enough to detect changes in the clepth to the water table greater than about one meter, using an infinite sheet approximation with a porosity of $25 \%$ and assuming that the configuration of the unsaturated zone remains the same.

The precision of this network is expected to increase with additional occupations. Moreover, the accuracy of such monitoring is expected to increase dramatically with the development of an advanced modification of a cryogenic gravity meter in progress by J. M. Cloodkind (written commun., 1988), originally concieved by Prothero and Goodkind (1968). This continuously recording instrument shows promise of measuring gravity changes of $1 \mu \mathrm{Gal}$ over a period of two weeks and $10 \mu \mathrm{Gal}$ over one year. Accuracy tests with two cryogenic meters at Yucca Mountain are being planned in 1989. 


\section{CONCLUSIONS}

A high-precision gravity network has been established over Yucca Mountain, Nevada in an effort to monitor fluctuations in the gravity field, and consists of eight accurately known observed gravity station pairs. The gravity loop has been reoccupied twice since it was established and biyearly occupations of the gravity loop are planned in the future.

Changes in relative gravity values between occupations may represent absolute changes in gravity at the gravity station or the absolute gravity bases (i.e. gravity datum), or both. Most of the stations have small overall gravity changes relative to their uncertainties implying that they have remained stable, although more occupations of the gravity network are needed to better constrain the data. Furthermore, additional absolute gravity measurements are needed at the absolute gravity bases to ensure that the gravity datum is known. As it now stands, additional monitoring of the gravity network, coupled with leveling surveys, and records of the depth to the water table, are needed to model and interpret changes in the gravity field. 


\section{REFERENCES}

Barnes, D. F., Oliver, H. W., and Robbins, S. L., 1969, Standardization of gravimeter calibrations in the Geological Survey: EOS (American Geophysical Union Transactions), v. 50, p. 526-527.

GWR Instruments, 1985, GWR superconducting gravity meter: GWR Instruments, San Diego, CA, 5 p.

Isherwood, W. F., 1977, Geothermal reservoir interpretation from change in gravity: Proceedings, Third Workshop on Geothermal Reservoir Engineering, Stanford University, Stanford, California, December 1977, p. 18-23.

Jachens, R. C., 1978, Temporal gravity changes applied to studies of crustal deformation, in Evernden, J. F., ed., Proceedings of Conference F, stress and strain measurements related to earthquake prediction: U.S. Geological Survey Open-File Report 79-370, p. 224-243.

Jachens, R., Eaton, G., Lipman, P. and Okamura, R., 1976, Temporal gravity variations associated with the November 1975 deflation of Kilauea Volcano (abs.): American Geophysical Union Tranactions, v. 57, p. $1,015-1,016$.

Jachens, R. C., Thatcher, Wayne, Roberts, C. W., and Stein, R. S., 1983, Correlation of changes in gravity, elevation, and strain in southern California: Science, v. 219, p. 1,215-1,217.

Longman, I. M., 1959, Formulas for computing the tidal accelerations due to the moon and sun: Journal of Geophysical Research, v. 64, p. 2,351-2,355.

Oliver H. W., Robbins, S. L., Gramnell, R. B., Alewine, R. W., and Biehler, Shawn, 1975, Surface and subsurface movements determined by remeasuring gravity, Chapt. 16 (p. 195-211), in Oakshott, G. B., ed., San Fernando earthquake of February 9, 1971: California Division of Mines and Geology Bulletin. $196,463 \mathrm{p}$.

Ponce, D. A., and Oliver, H. W., 1981, Charleston Peak gravity calibration loop, Nevada: U.S. Geological Survey Open-File Report 81-985, 20 p.

Prothero, W. A., and Goodkind, J. M., 1968, A superconducting gravimeter: The Review of Scientific Instruments, v. 39 , no. 9, p. $1,257-1,262$.

U.S. Department of Energy, 1988, Consultation Draft, Site characterization plan, Yucca Mountain Site, Nevada Research and Development Area, Nevada: U.S. Department of Energy Report RW-0160, 7 volumes.

U.S. Geological Survey, 1984, A summary of geologic studies through 1983 of a potential high-level radioactive waste disposal site at Yucca Mountain, southern Nye County, Nevada: U.S. Geological Survey Open-File Report 84-794, $140 \mathrm{p}$.

Zumberge, M. A., Harris, R. N., Oliver, H. W., Sasagawa, G. S., and Ponce, D. A., 1988, Preliminary results of absolute and high-precision gravity measurements at the Nevada Test Site and vicinity, Nevada, U.S. Geological Survey Open-File Report 88-242, 13 p. 


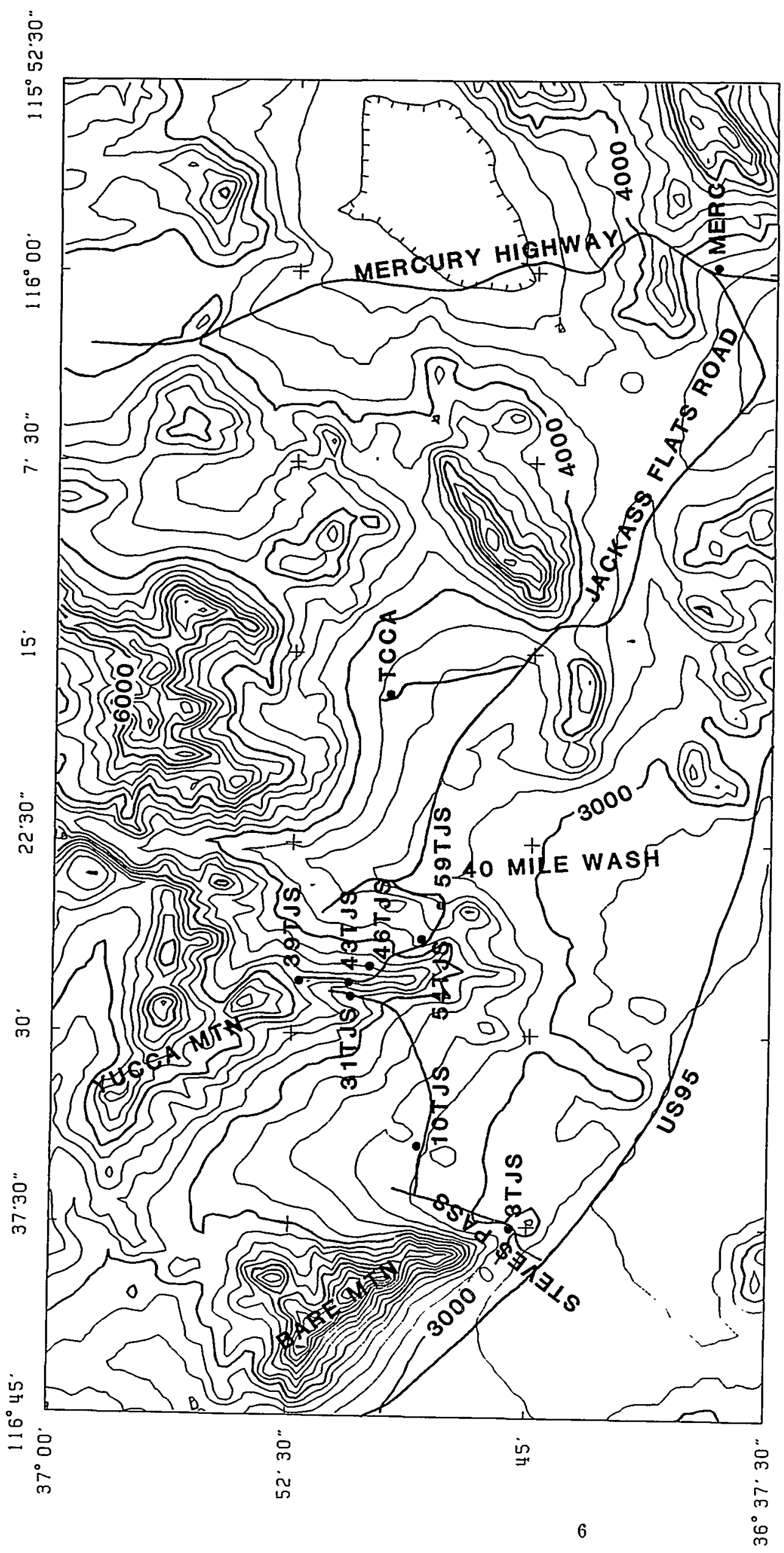

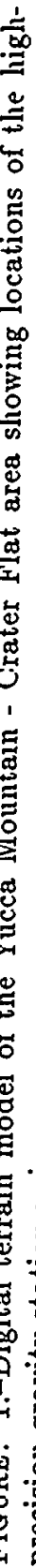




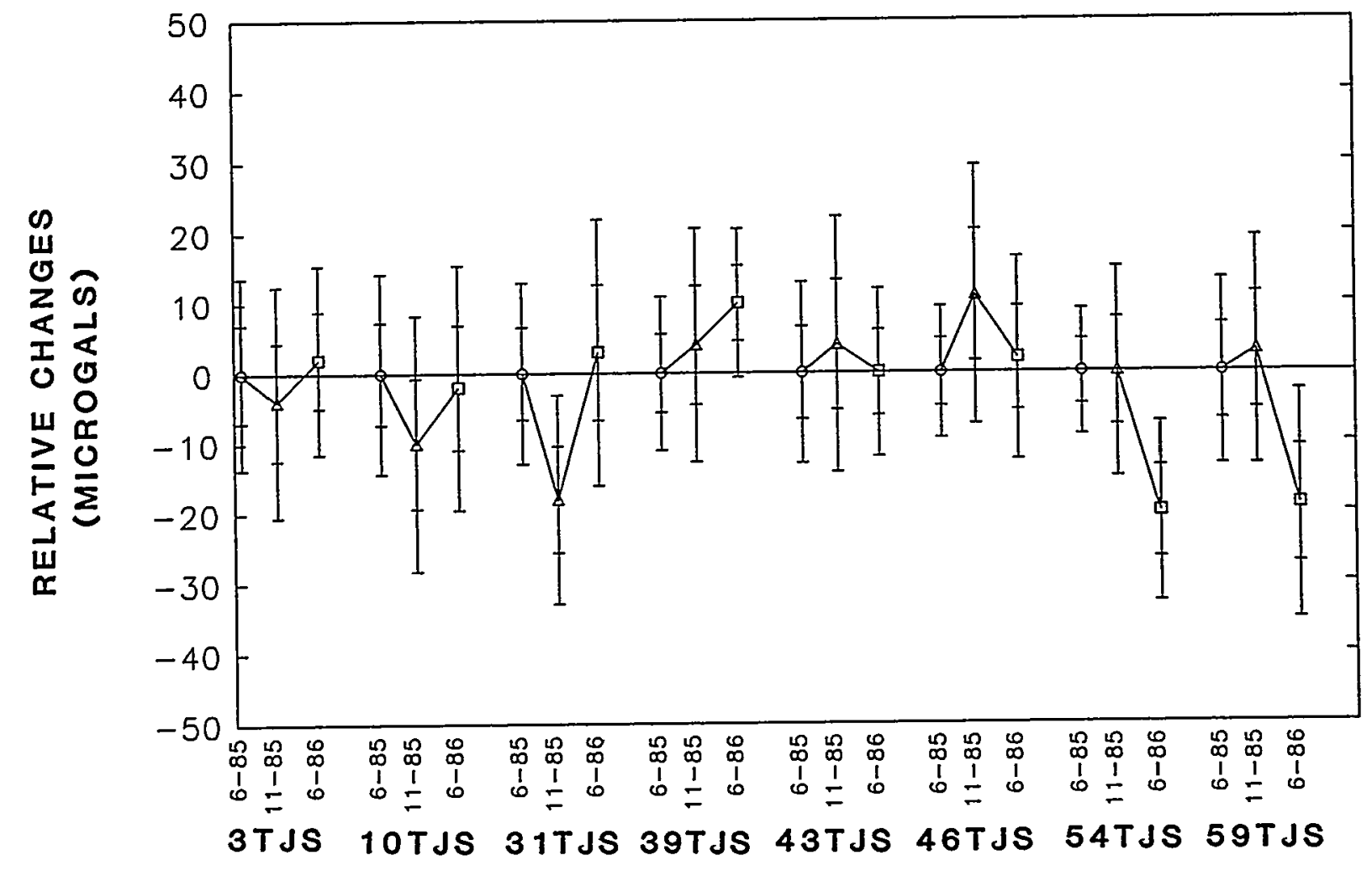

FIGURE. 2.-Plot of average changes in gravity of station pairs. $\circ-J u n e, 1985$ occupation. $\triangle-$ November, 1985 occupation. $\square-$ June, 1986 occupation. Error bars show 68 and $95 \%$ confidence intervals. 
Table 1.-LaCoste and Romberg Meters used and their calibration correction factors

\begin{tabular}{rc}
\hline Meter & Correction factors \\
\hline D-26 & 1.000999 \\
G161 & 1.000573 \\
G614 & 1.000380 \\
\hline
\end{tabular}

Table 2.-Gravity differences (in $\mathrm{mGal}$ ) for the Yucca Mountain high-precision loop relative to absolute gravity station MERCA at Mercury, Nevada based on a value of $979,518.874 \mathrm{mGal}$.

\begin{tabular}{ccccccc}
\hline & \multicolumn{2}{c}{ June 1985} & \multicolumn{2}{c}{ November 1985} & \multicolumn{2}{c}{ June 1986} \\
\hline Station & $\begin{array}{c}\text { Relative } \\
\text { gravity }\end{array}$ & $\begin{array}{c}\text { Standard } \\
\text { error }\end{array}$ & $\begin{array}{c}\text { Relative } \\
\text { gravity }\end{array}$ & $\begin{array}{c}\text { Standard } \\
\text { error }\end{array}$ & $\begin{array}{c}\text { Relative } \\
\text { gravity }\end{array}$ & $\begin{array}{c}\text { Standard } \\
\text { error }\end{array}$ \\
\hline 3TJS & 68.076 & 0.0036 & 68.071 & 0.0092 & 68.068 & 0.0056 \\
3A & 67.779 & 0.0043 & 67.777 & 0.0055 & 67.792 & 0.0057 \\
10TJS & 21.959 & 0.0068 & 21.946 & 0.0093 & 21.960 & 0.0048 \\
10A & 21.878 & 0.0085 & 21.871 & 0.0016 & 21.873 & 0.0045 \\
31TJS & -42.298 & 0.0066 & -42.311 & 0.0047 & -42.291 & 0.0076 \\
31A & -42.546 & 0.0062 & -42.570 & 0.0037 & -42.547 & 0.0070 \\
39TJS & -91.362 & 0.0056 & -91.359 & 0.0070 & -91.349 & 0.0023 \\
39A & -91.269 & 0.0049 & -91.264 & 0.0071 & -91.262 & 0.0029 \\
43TJS & -94.960 & 0.0060 & -94.953 & 0.0072 & -94.960 & 0.0032 \\
43A & -94.886 & 0.0040 & -94.884 & 0.0084 & -94.887 & 0.0038 \\
46TJS & -56.730 & 0.0048 & -56.722 & 0.0078 & -56.726 & 0.0047 \\
46A & -57.472 & 0.0074 & -57.457 & 0.0065 & -57.471 & 0.0038 \\
54TJS & 5.465 & 0.0046 & 5.458 & 0.0058 & 5.445 & 0.0032 \\
54A & 5.268 & 0.0063 & 5.276 & 0.0051 & 5.248 & 0.0041 \\
59TJS & 25.763 & 0.0068 & 25.756 & 0.0021 & 25.735 & 0.0032 \\
59A & 25.750 & 0.0085 & 25.763 & 0.0047 & 25.740 & 0.0036 \\
\hline
\end{tabular}


Table 3.-Average differences in $\mathrm{mGal}$ of station pairs relative to June, 1985

\begin{tabular}{lcccc}
\hline & \multicolumn{2}{c}{ November 1985} & \multicolumn{2}{c}{ June 1986} \\
\hline $\begin{array}{l}\text { Station } \\
\text { Pair }\end{array}$ & $\begin{array}{c}\text { Avg. } \\
\text { diff. }\end{array}$ & $\begin{array}{c}\text { Std. } \\
\text { error }\end{array}$ & $\begin{array}{r}\text { Avg. } \\
\text { diff. }\end{array}$ & $\begin{array}{r}\text { Std. } \\
\text { error }\end{array}$ \\
\hline 3TJS & -0.004 & 0.0084 & 0.002 & 0.0069 \\
10TJS & -0.010 & 0.0093 & -0.002 & 0.0089 \\
31TJS & -0.018 & 0.0076 & 0.003 & 0.0097 \\
39TJS & 0.004 & 0.0085 & 0.010 & 0.0054 \\
43TJS & 0.004 & 0.0093 & 0.000 & 0.0061 \\
46TJS & 0.011 & 0.0094 & 0.002 & 0.0074 \\
54TJS & 0.000 & 0.0076 & -0.020 & 0.0065 \\
59TJS & 0.003 & 0.0083 & -0.019 & 0.0083 \\
\hline
\end{tabular}




\section{APPENDIX}

\section{Description of Gravity Base Station: 3 TJS}

\begin{tabular}{|c|c|c|c|c|c|}
\hline Name & State & $\begin{array}{c}\text { Latitude } \\
\text { deg min }\end{array}$ & $\begin{array}{c}\text { Longitude } \\
\text { deg min }\end{array}$ & Elevation & $\begin{array}{c}\text { Observed Gravity } \\
\text { mGal }\end{array}$ \\
\hline 3 TJS & Nevada & 3645.55 & 11637.56 & $904.04 \mathrm{~m}(2966.0 \mathrm{ft})$ & $979,586.950$ \\
\hline
\end{tabular}

Station 3 TJS is $23.3 \mathrm{~km}$ (14.5 mi) east along U.S. Highway 95 from Lathrop Wells (Amargosa Valley), then $2.9 \mathrm{~km}(1.8 \mathrm{mi})$ north along bladed road to Steves Pass. Station is $38 \mathrm{~m}(125 \mathrm{ft})$ west of road and about $5 \mathrm{~m}$ $(15 \mathrm{ft})$ higher than road in limestone. Read, facing north, over benchmark with base plate legs in star-drilled holes.

Alternate: Station $3 \mathrm{~A}$ is about $9 \mathrm{~m}(30 \mathrm{ft})$ north and $6 \mathrm{~m}(20 \mathrm{ft})$ higher than 3 TJS. Site is monumented with a $3.5 \mathrm{~cm}$ brass disc marked $3 A$. Read facing north, over disc, with base plate legs in star-drilled holes. Observed gravity: $979,586.653 \mathrm{mGal}$.

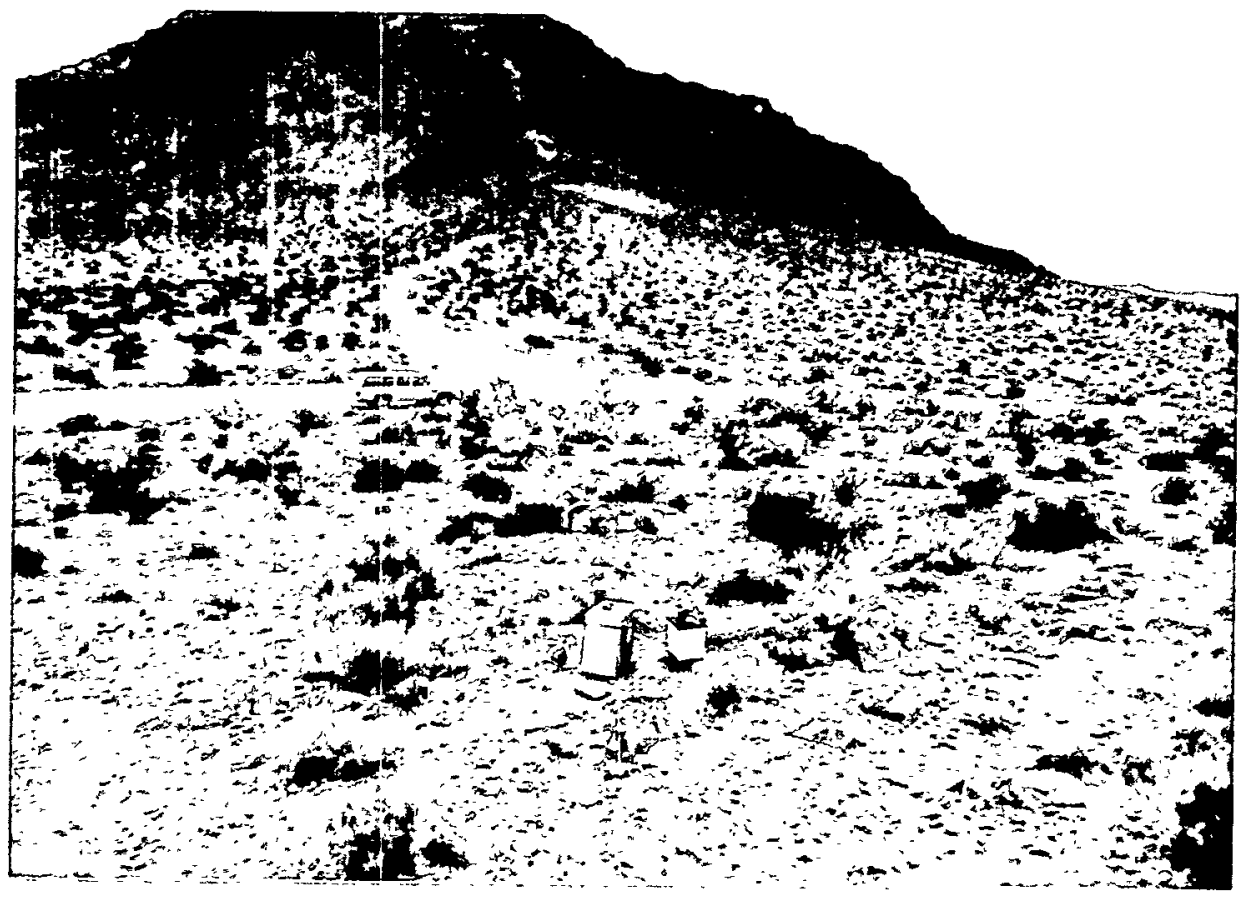




\section{Description of Gravity Base Station: 10 TJS}

\begin{tabular}{|c|c|c|c|c|c|}
\hline Name & State & $\begin{array}{c}\text { Latitude } \\
\text { deg min }\end{array}$ & $\begin{array}{c}\text { Longitude } \\
\text { deg min }\end{array}$ & $\begin{array}{c}\text { Elevation } \\
\text { mGal Gravity }\end{array}$ \\
\hline 10 TJS & Nevada & 3648.48 & 11634.37 & $984.50 \mathrm{~m}(3230.0 \mathrm{ft})$ & $979,540.833$ \\
\hline
\end{tabular}

Station 10TJS is $6.1 \mathrm{~km}$ (3.8 mi) north of 3TJS along road leading to Crater Flat, then $2.4 \mathrm{~km}(1.5 \mathrm{mi})$ east along dirt road and $1.0 \mathrm{~km}(0.6 \mathrm{mi})$ along spur to drill hole USW VH-2, then $0.3 \mathrm{~km}(0.2 \mathrm{mi})$ along jeep trail to base of basalt outcrop. Read, facing north, over benchmark with base plate legs in star-drilled holes.

Alternate: Station $10 \mathrm{~A}$ is $4.6 \mathrm{~m}(15 \mathrm{ft})$ west and $0.6 \mathrm{~m}(2 \mathrm{ft})$ higher than station $10 \mathrm{TJS}$. Site is monumented with a $3.5 \mathrm{~cm}$ brass disc marked $10 \mathrm{~A}$. Read facing north, over disc, with base plate legs in star-drilled holes. Observed gravity: $979,540.752 \mathrm{mGal}$.

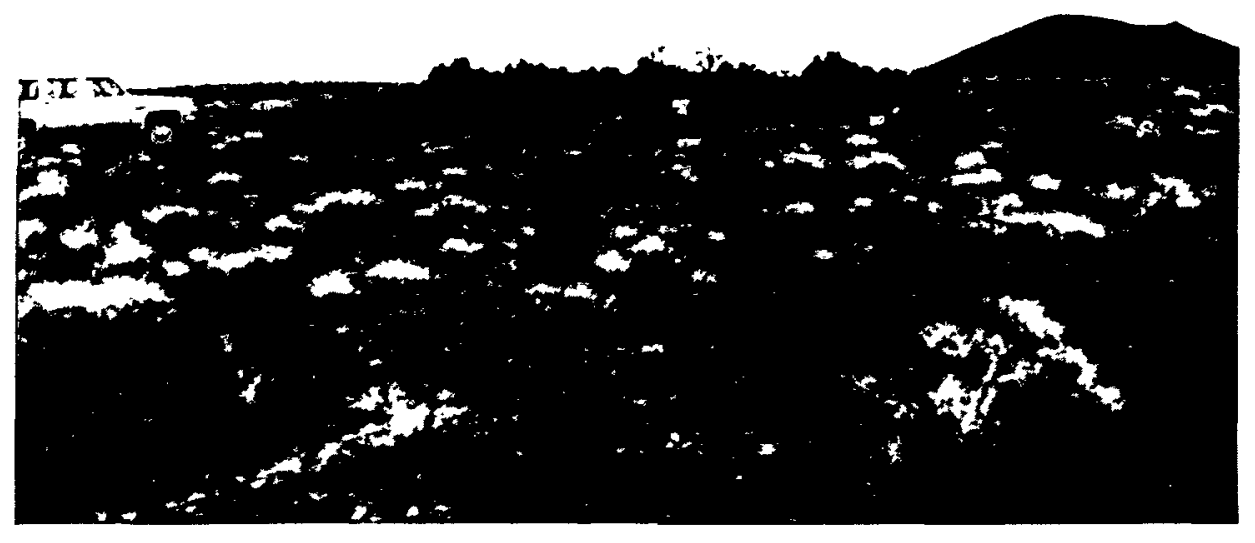




\section{Description of Gravity Base Station: 31 TJS}

\begin{tabular}{|c|c|c|c|c|c|}
\hline Name & State & $\begin{array}{c}\text { Latitude } \\
\text { deg } \min \end{array}$ & $\begin{array}{c}\text { Longitude } \\
\text { deg } \min \end{array}$ & Elevation & $\begin{array}{c}\text { Observed Gravity } \\
\text { mGal }\end{array}$ \\
\hline 31 TJS & Nevada & 3650.65 & 11628.53 & $1269.46 \mathrm{~m}(4164.9 \mathrm{ft})$ & $979,476.576$ \\
\hline
\end{tabular}

Station $31 \mathrm{TJS}$ is about $16.4 \mathrm{~km}$ (10.2 mi) east of intersection of the road over Steves Pass and the road along the TJS line. Station is $24 \mathrm{~m}(80 \mathrm{ft})$ north of road and at same level. Read, facing north, over benchmark with base plate legs in star-drilled holes.

Alternate: Station $31 \mathrm{~A}$ is about $9 \mathrm{~m}(30 \mathrm{ft})$ northwest and $.6 \mathrm{~m}(2 \mathrm{ft})$ higher than 31TJS. Site is monumented with a $3.5 \mathrm{~cm}$ brass disc marked $31 \mathrm{~A}$. Read facing north, over disc, with base plate legs in star-drilled holes. Observed gravity: $979,476.328 \mathrm{mGal}$.

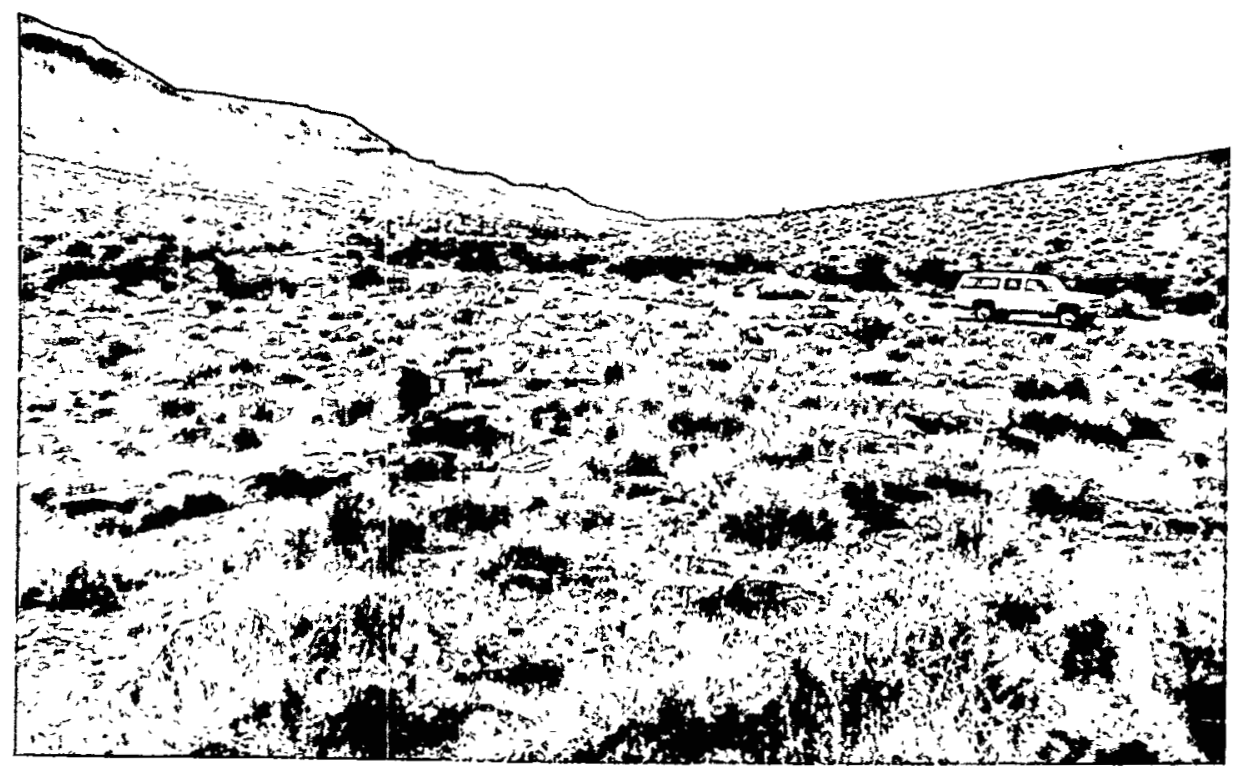


Description of Gravity Base Station: 39 TJS

\begin{tabular}{|c|c|c|c|c|c|}
\hline Name & State & $\begin{array}{c}\text { Latitude } \\
\text { deg min }\end{array}$ & $\begin{array}{c}\text { Longitude } \\
\text { deg min }\end{array}$ & Elevation & $\begin{array}{c}\text { Observed Gravity } \\
\text { mGal }\end{array}$ \\
\hline 39 TJS & Nevada & 3652.28 & 11627.95 & $1480.87 \mathrm{~m}(4858.5 \mathrm{ft})$ & $979,427.512$ \\
\hline
\end{tabular}

From Mercury, Nev., station 39TJS is $43 \mathrm{~km}(27 \mathrm{mi})$ north along Jackass Flats road then $2.9 \mathrm{~km}(1.8 \mathrm{mi})$ west along Cane Spring Road, then north $10 \mathrm{~km}$ (6.4 mi) along road to Fortymile Wash and Yucca Mountain. Then south on dirt road to ridge of Yucca Mountain $15.3 \mathrm{~km}(9.5 \mathrm{mi})$. Station 39TJS is at the end of the road and $38 \mathrm{~m}(125 \mathrm{ft})$ west and $3 \mathrm{~m}$ (10 ft) lower than the road. Read, facing north, over benchmark with base plate legs in star-drilled holes.

Alternate: Station $39 \mathrm{~A}$ is about $3 \mathrm{~m}$ (10 ft) southwest of $39 \mathrm{TJS}$. Site is monumented with a $3.5 \mathrm{~cm}$ brass disc marked $39 A$. Read facing north, over disc, with base plate legs in star-drilled holes. Obseved gravity: $979,427.605 \mathrm{mGal}$.

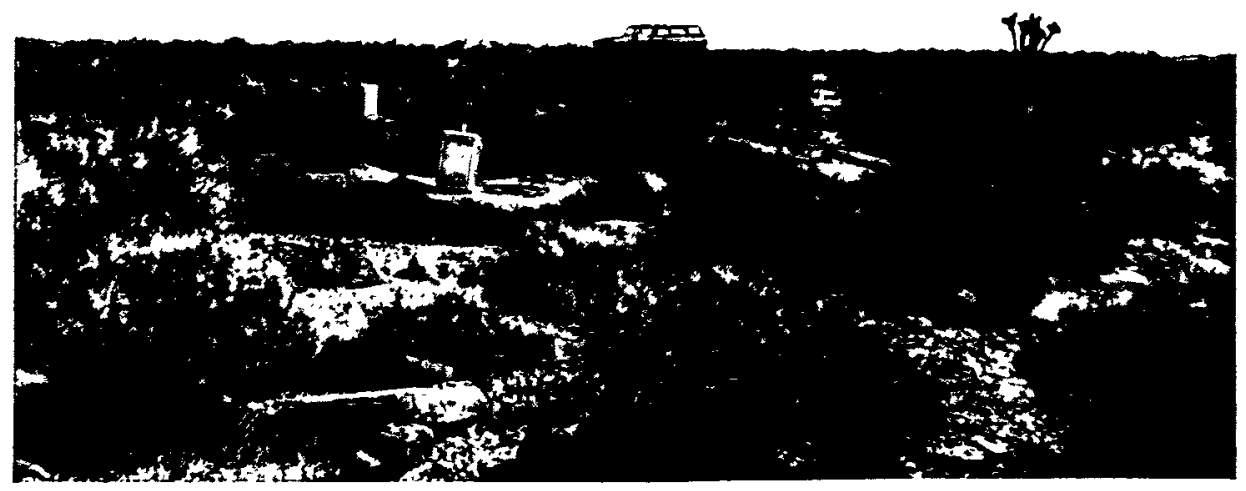




\section{Description of Gravity Base Station: $43 T J S$}

\begin{tabular}{|c|c|c|c|c|c|}
\hline Name & State & $\begin{array}{c}\text { Latitude } \\
\text { deg min }\end{array}$ & $\begin{array}{c}\text { Longitude } \\
\text { deg min }\end{array}$ & Elevation & $\begin{array}{c}\text { Observed Gravity } \\
\text { mGal }\end{array}$ \\
\hline 43 TJS & Nevada & $\mathbf{3 6 5 0 . 7 2}$ & $\mathbf{1 1 6 2 7 . 9 9}$ & $1496.02 \mathrm{~m}(4908.2 \mathrm{ft})$ & $\mathbf{9 7 9 , 4 2 3 . 9 1 4}$ \\
\hline
\end{tabular}

From Mercury, Nev., station 43TJS is $43 \mathrm{~km}$ (27 mi) north along Jackass Flats road, then $2.9 \mathrm{~km}(1.8 \mathrm{mi})$ west along Cane Spring Road, then north $10 \mathrm{~km}(6.4 \mathrm{mi})$ along road to Fortymile Wash and Yucca Mountain, then south on dirt road to ridge of Yucca Mountain $12.4 \mathrm{~km}(7.7 \mathrm{mi})$. Station 43 TJS is $12 \mathrm{~m}$ (40 ft) west of road and $0.6 \mathrm{~m}(2 \mathrm{ft})$ higher. Read, facing north, over benchmark with base plate legs in star-drilled holes.

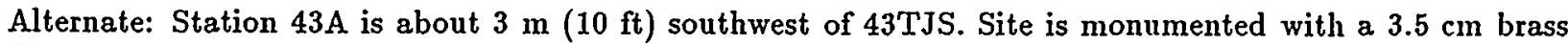
disc marked $3 A$. Read facing north, over disc, with base plate legs in star-drilled holes. Observed gravity: $979,423.988 \mathrm{mGal}$.

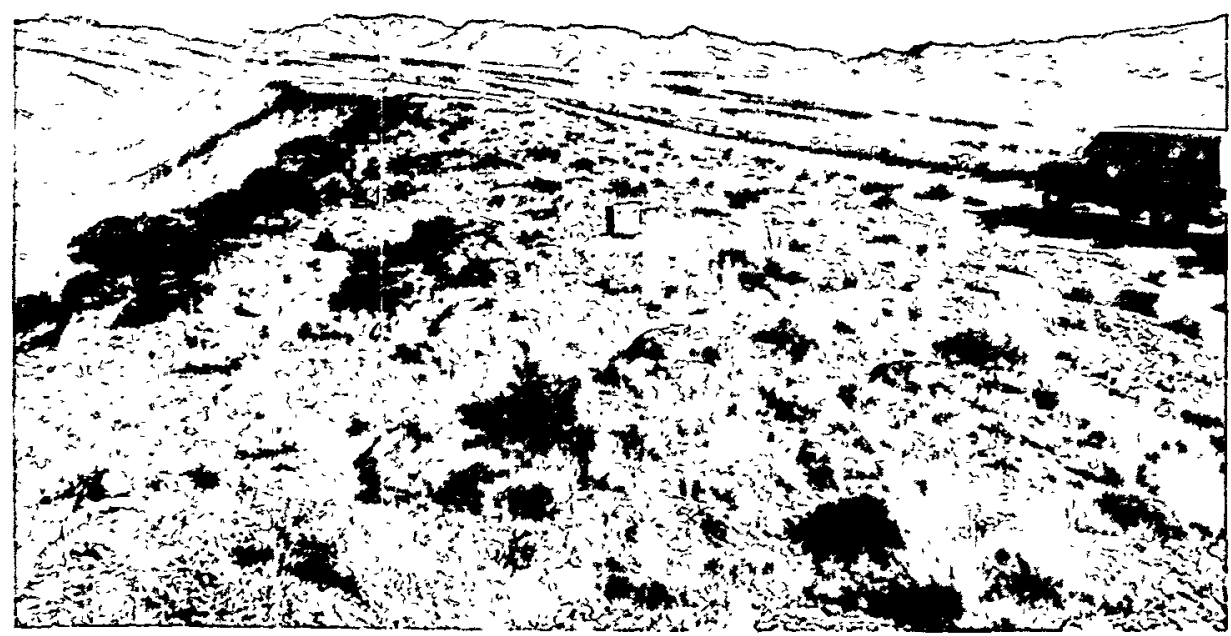




\section{Description of Gravity Base Station: 46 TJS}

\begin{tabular}{|c|c|c|c|c|c|}
\hline Name & State & $\begin{array}{c}\text { Latitude } \\
\text { deg min }\end{array}$ & $\begin{array}{c}\text { Longitude } \\
\text { deg min }\end{array}$ & Elevation & $\begin{array}{c}\text { Observed Gravity } \\
\text { InGal }\end{array}$ \\
\hline 46 TJS & Nevada & 3650.06 & 11627.35 & $1355.99 \mathrm{~m}(4448.7 \mathrm{ft})$ & $979,462.144$ \\
\hline
\end{tabular}

From Mercury, Nev., station $46 \mathrm{TJS}$ is $43 \mathrm{~km}$ (27 mi) north along Jackass Flats road, then $2.9 \mathrm{~km}$ (1.8 mi) west along Cane Spring Road, then north $10 \mathrm{~km}(6.4 \mathrm{mi})$ along road to Fortymile Wash and Yucca Mountain, then south on dirt road to ridge of Yucca Mountain $10 \mathrm{~km}$ (6.4 mi). Station 46TJS is $12 \mathrm{~m} \mathrm{(40}$ $\mathrm{ft}$ ) north of road and $6 \mathrm{~m}(20 \mathrm{ft})$ higher than road. Read, facing north, over benchmark with base plate legs in star-drilled holes.

Alternate: Station $46 \mathrm{~A}$ is about $27 \mathrm{~m}(90 \mathrm{ft})$ north and $2 \mathrm{~m}(6 \mathrm{ft})$ ligher than $46 \mathrm{TJS}$. Site is monumented with a $3.5 \mathrm{~cm}$ brass disc marked $3 A$. Read facing north, over disc, with base plate legs in star-drilled holes. Observed gravity: $979,461.402 \mathrm{mGal}$.

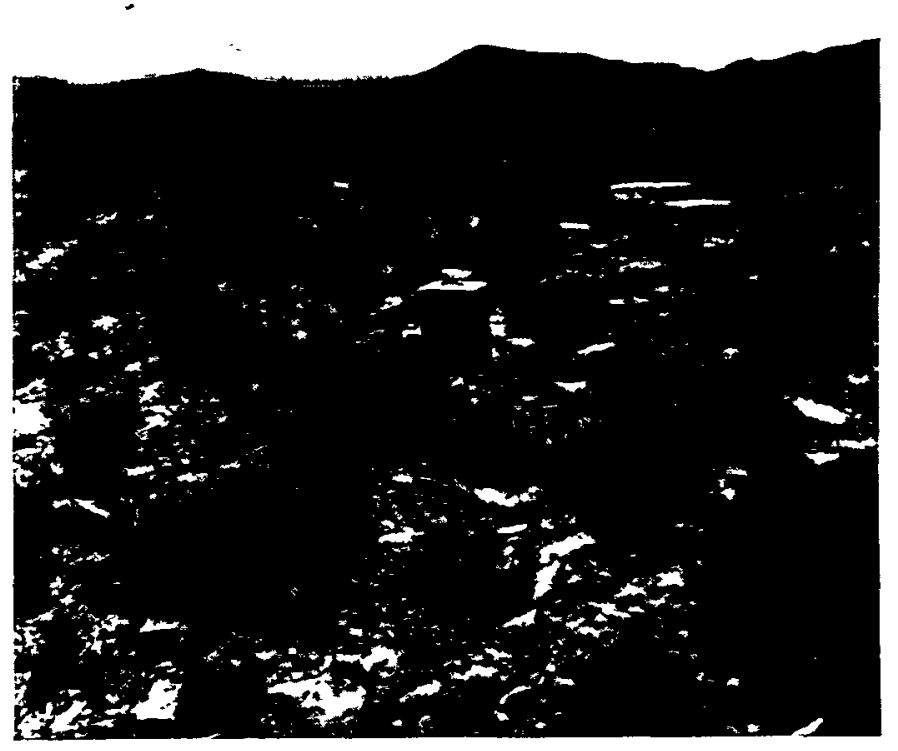




\section{Description of Gravity Base Station: 54 TJS}

\begin{tabular}{|c|c|c|c|c|c|}
\hline Name & State & $\begin{array}{c}\text { Latitude } \\
\text { deg min }\end{array}$ & $\begin{array}{c}\text { Longitude } \\
\text { deg min }\end{array}$ & Elevation & $\begin{array}{c}\text { Observed Gravity } \\
\text { mGal }\end{array}$ \\
\hline 54 TJS & Nevada & 3648.43 & 11626.27 & $1110.05 \mathrm{~m}(3641.9 \mathrm{ft})$ & $979,524.339$ \\
\hline
\end{tabular}

From Mercury, Nev., station 54 TJS is $43 \mathrm{~km}$ (27 mi) north along Jackass Flats road, then $2.9 \mathrm{~km} \mathrm{(1.8} \mathrm{mi})$ west along Cane Spring Road, then north $10 \mathrm{~km}(6.4 \mathrm{mi})$ along road to Fortymile Wash and Yucca Mountain, then south on dirt road to ridge of Yucca Mountain $6 \mathrm{~km}(3.8 \mathrm{mi})$. Station 54 TJS is $9 \mathrm{~m}$ (30 ft) north of

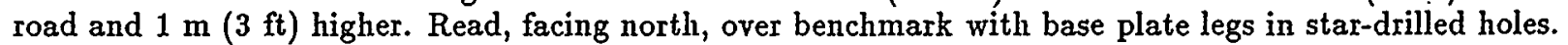

Alternate: Station $54 \mathrm{~A}$ is about $4 \mathrm{~m}(15 \mathrm{ft})$ west and $1 \mathrm{~m}(4 \mathrm{ft})$ higher than 54 TJS. Site is monumented with a $3.5 \mathrm{~cm}$ brass disc marked $3 A$. Read facing north, over disc, with base plate legs in star-drilled holes. Observed gravity: $979,524.142 \mathrm{mGal}$.

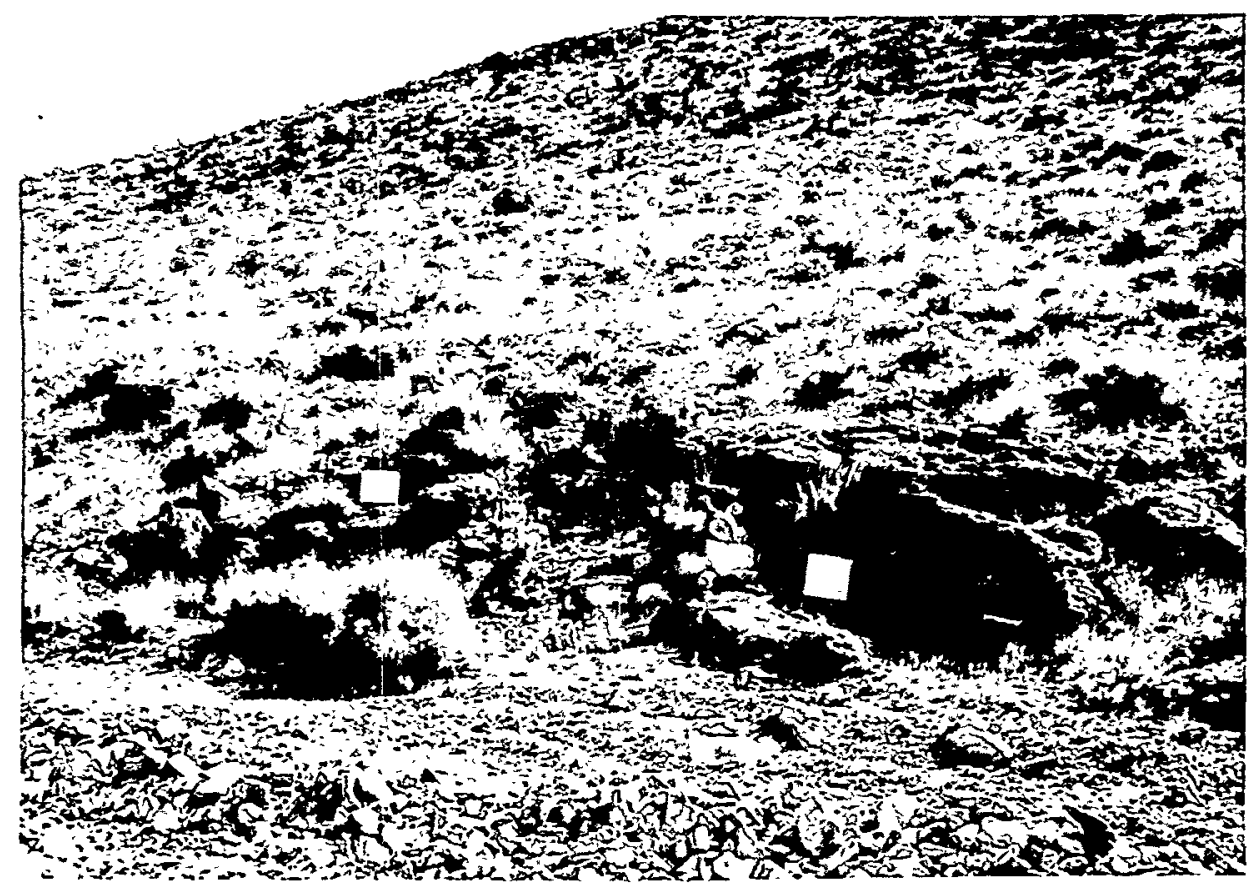




\section{Description of Gravity Base Station: 59 TJS}

\begin{tabular}{|c|c|c|c|c|c|}
\hline Name & State & $\begin{array}{l}\text { Latitude } \\
\text { deg min }\end{array}$ & $\begin{array}{l}\text { Longitude } \\
\text { deg min }\end{array}$ & Elevation & $\begin{array}{c}\text { Observed Gravity } \\
\mathrm{mGal}\end{array}$ \\
\hline 59 TJS & Nevada & 3647.84 & 11624.93 & $1026.6 \mathrm{~m}(3368.2 \mathrm{ft})$ & $979,544.637$ \\
\hline
\end{tabular}

From Mercury, Nev., station 59TJS is $43 \mathrm{~km}$ (27 mi) north along Jackass Flats road, then $2.9 \mathrm{~km}(1.8 \mathrm{mi})$ west along Cane Spring Road, then north $10 \mathrm{~km}(6.4 \mathrm{mi})$ along road to Fortymile Wash and Yucca Mountain, then south on dirt road to ridge of Yucca Mountain $6.4 \mathrm{~km}(4 \mathrm{mi})$ to spur. Then along spur $0.3 \mathrm{~km}(0.2$ mi). Station 59TJS is $1 \mathrm{~m}$ (4 ft) higher than road. Read, facing north, over benchmark with base plate legs in star-drilled holes.

Alternate: Station 59A is about $4.5 \mathrm{~m}(15 \mathrm{ft})$ west and $.3 \mathrm{~m}(1 \mathrm{ft})$ higher than 59TJS. Site is monumented with a $3.5 \mathrm{~cm}$ brass disc. Read facing hill, over disc, with base plate legs in star-drilled holes. Observed gravity: $979,544.624 \mathrm{mGal}$.

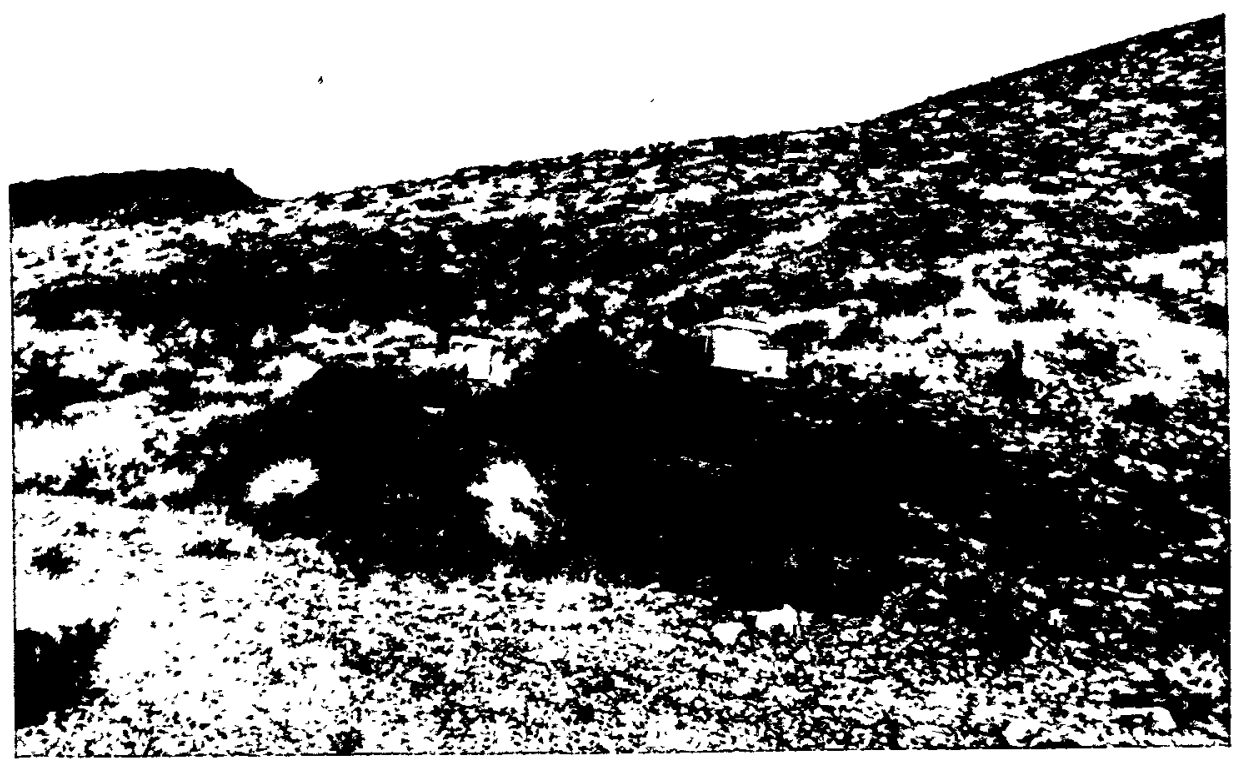




\section{Description of Gravity Base Station: $M E R C A$}

\begin{tabular}{|c|c|c|c|c|c|}
\hline $\mathrm{N}$ & Sta & $\begin{array}{l}\text { Latitude } \\
\text { deg min }\end{array}$ & $\begin{array}{l}\text { Longitude } \\
\text { deg min }\end{array}$ & Elevation & $\begin{array}{c}\text { Absolute Gravity } \\
\text { mGal }\end{array}$ \\
\hline MERCA & Nevada & 3639.35 & 11559.75 & $1,152 \mathrm{~m}(3,780 \mathrm{ft})$ est. & $979,518.520(109 \mathrm{~cm})$ \\
\hline
\end{tabular}

Absolute gravity station at Mercury, Nev., about $112 \mathrm{~km}$ (70 mi) northwest of Las Vegas along U.S. Higliway 95. Located in the southwest corner of the U.S. Geological Survey Core Library building, Nevada Test Site, in a rear storage room, near the geophysics workbench, about $6 \mathrm{~m}(20 \mathrm{ft})$ south-southeast of gravity station MERC (Ponce and Oliver, 1981, p. 13). The station is marked with a standard USGS gravity base station disc stamped MERCA 1984. Align the gravity base plate legs in the star-drilled holes, read over the gravity disc with the meter facing north.

Free-air gradient $3.25 \mu \mathrm{Gal} / \mathrm{cm}$

Absolute gravity at $109 \mathrm{~cm}$ above floor $979,518.520 \mathrm{mGal}$

Absolute gravity at floor $979,518.820 \mathrm{mGal}$

Address and contact at measurment site:

Andy Benton, Secretary

U.S. Geological Survey

Box 327

Mercury, NV 89023

702 295-7016, FTS 575-7016

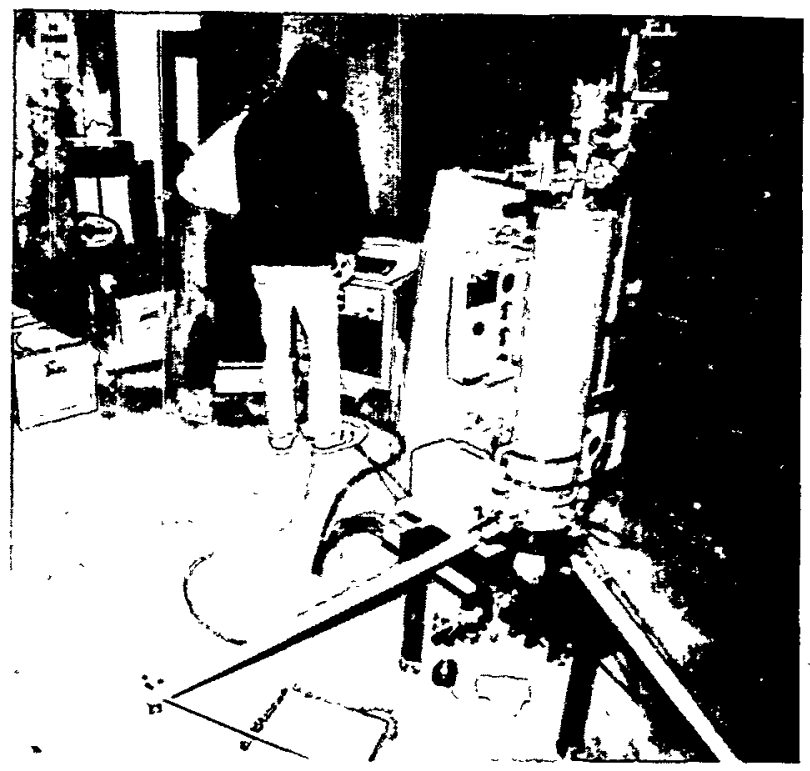




\section{Description of Gravity Base Station: TCCA}

\begin{tabular}{|c|c|c|c|c|c|}
\hline Name & State & $\begin{array}{l}\text { Latitude } \\
\text { deg min }\end{array}$ & $\begin{array}{l}\text { Longitude } \\
\text { deg min }\end{array}$ & Elevation & $\begin{array}{c}\text { Absolute Gravity } \\
\text { mGal }\end{array}$ \\
\hline $\mathrm{TCCA}$ & Nevada & 3649.50 & 11616.64 & $1,158 \mathrm{~m}(3,800 \mathrm{ft})$ est. & $979,509.66(109 \mathrm{~cm})$ \\
\hline
\end{tabular}

Absolute gravity station at the Test Cell $\mathrm{C}$ administration building, Nevada Test Site, Nev. about $32 \mathrm{~km}$ $(20 \mathrm{mi})$ from Mercury, Nev., along Jackass Flats Road, then about $0.12 \mathrm{~km}(0.08 \mathrm{mi})$ northwest along spur road to Test Cell C. Located in the center of office no. 22 in the northeast corner of building. Test Cell $\mathrm{C}$ is the USGS Nuclear Hydrology office. The station is marked with a standard USGS gravity station disc stamped TCCA 1984. Align the gravity base plate legs in the star-drilled holes, read over the gravity disc with the meter facing north.

Free-air gradient $3.15 \mu \mathrm{Gal}$

Absolute gravity at $109 \mathrm{~cm}$ above floor $979,509.664 \mathrm{mGal}$

Absolute gravity at floor $979,510.007 \mathrm{mGal}$

Address and contact at measurement site:

Chuck Warren, Representative

Test Cell C Administrative Building

Building 3229

Nevada Test Site, NV 89023

702 295-5973, FTS 575-5973

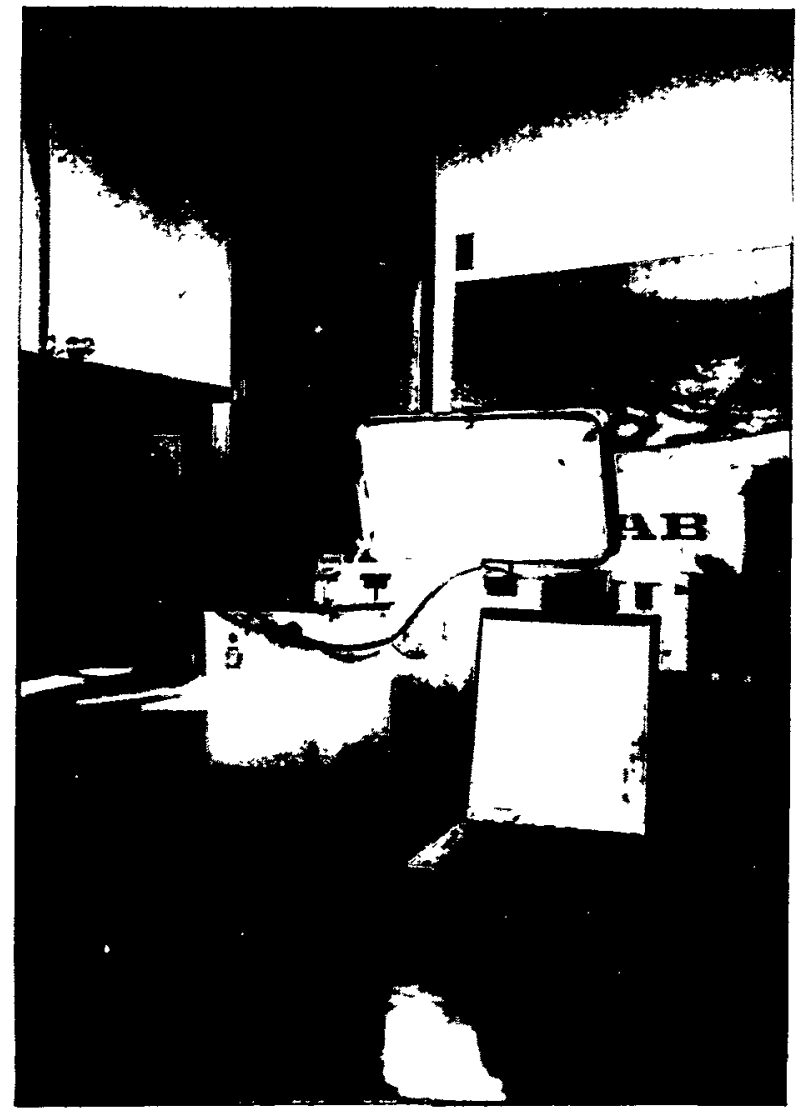

